THE PRESERVATION OF FRUIT AND VEGETABLE FOOD PRODUCTS 


\section{Science in Horticulture Series}

General Editor: L. Broadbent, formerly Professor of Horticulture, University of Bath

Published in collaboration with the Royal Horticultural Society and the Horticultural Education Association.

This series of texts has been designed for students on courses in horticulture at the Higher National Certificate Diploma level, but care has been taken to ensure that they are neither too specialised for lower-level courses, nor too superficial for university work.

All the contributors to the series have had experience in both the horticultural industry and education. Consequently, the books have a strong practical flavour which should reinforce their value as textbooks and also make them of interest to a wide audience, including growers and farmers, extension officers, research workers and workers in the agrochemical, marketing and allied industries, and the many gardeners who are interested in the science behind their hobby.

The authors are all British but they have illustrated their books with examples drawn from many countries. As a result the text should be of value to English-speaking students of horticulture throughout the world.

Other titles in the series are:

J. K. A. Bleasdale, Plant Physiology in Relation to Horticulture, second edition

G. R. Dixon, Plant Pathogens and their Control in Horticulture

A. W. Flegmann and R. A. T. George, Soils and Other Growth Media

C. North, Plant Breeding and Genetics in Horticulture

M. J. Sargent, Economics in Horticulture

R. J. Stephens, Theory and Practice of Weed Control

E. J. Winter, Water, Soil and the Plant 


\title{
THE PRESERVATION OF FRUIT AND VEGETABLE FOOD PRODUCTS
}

\author{
S. D. HOLDSWORTH \\ Campden Food Preservation Research Association \\ Chipping Campden \\ Gloucestershire
}

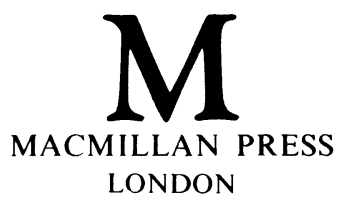


(C) S. D. Holdsworth 1983

All rights reserved. No part of this publication

may be reproduced or transmitted, in any

form or by any means, without permission.

First published 1983 by

THE MACMILLAN PRESS LTD

London and Basingstoke

Companies and representatives

throughout the world

ISBN 978-0-333-32292-5

DOI 10.1007/978-1-349-06153-2

ISBN 978-1-349-06153-2 (eBook)

To my wife, Margaret, and children, Christopher, Martin, Giles and Sarah 


\section{CONTENTS}

Preface

viii

1 INTRODUCTION 1

1.1 Food Preservation 1

1.2 Main Methods of Preservation 2

1.3 Fruits, Vegetables and their Products 3

1.4 Production of Processed Fruits and Vegetables 4

2 PRINCIPLES OF PRESERVATION 9

2.1 Main Causes of Deterioration 9

2.2 Structure and Physiology of Plant Produce 12

2.3 Principles of Preservation 16

Further Reading $\quad 23$

3 RAW MATERIAL - PRODUCTION AND POST-HARVEST

PREPARATION

3.1 Raw-material Production 25

3.2 Harvesting, Handling and Transport 29

3.3 Post-harvest Preparation 33

Further Reading $\quad 40$

4 THERMAL PROCESSING 42

4.1 Process Operations 42

4.2 Containers - Metallic, Glass and Plastic - Filling and Seaming $\quad 42$

4.3 Processing 51

4.4 Aseptic Processing and Packaging 58

4.5 Examination of Canned Foods 59

4.6 Some Typical Processes for Fruits and Vegetables 61

4.7 Nutritive Value of Canned Fruits and Vegetables 64

Further Reading 65

5 FREEZING 66

5.1 Introduction 66

5.2 Flow Sheet 66

5.3 Typical Freezing Operations 67

5.4 Packaging Materials for Frozen Foods 73 
5.5 Storage and Distribution of Frozen Foods - the

Cold Chain

Further Reading $\quad 77$

6 DEHYDRATION 78

6.1 Introduction and Flowsheet 78

6.2 Dehydration Processes 78

6.3 Technology of Dried-product Production 84

6.4 Fruit Drying 87

6.5 Drying Tomato Products 87

6.6 Dried Fruit Juices 88

6.7 Packaging and Storage of Dried Products 88

6.8 Quality and Nutritive Value 89

6.9 Intermediate-moisture Foods 89

Further Reading $\quad 90$

7 EXTENSION OF SHELF-LIFE BY STORAGE TECHNIQUES 91

7.1 Chilling and Refrigerated Storage 91

7.2 Recommended Conditions for the Storage of Fresh Fruits and Vegetables $\quad 95$

7.3 Modified-atmosphere Storage Techniques 98 Further Reading 103

8 OTHER METHODS OF PRESERVATION 104

$\begin{array}{lll}\text { 8.1 Sugar as a Preservative } & 104\end{array}$

8.2 Fermented Products 109

8.3 Other Methods of Chemical Preservation 112

$\begin{array}{ll}8.4 & \text { Irradiation } \\ & 115\end{array}$

9 FRUIT AND VEGETABLE JUICES AND RELATED PRODUCTS

9.1 Fruit Juices $\quad 116$

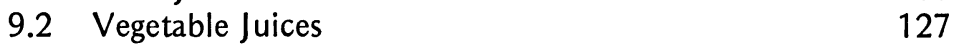

Further Reading 128

10 DESIRABLE AND UNDESIRABLE CONSTITUENTS OF FOOD

10.1 Nutritional Status of Processed Foods 129

10.2 Undesirable Constituents of Food 135

Further Reading

11 FOOD-PROCESSING FACTORY LOCATION, DESIGN AND OPERATION

11.1 Food-processing Factory Location

11.2 Factory Design and Construction

11.3 Factory Services

11.4 Economics of Production Operations 
11.5 Material and Energy Balances

11.6 Energy Use in Food Preservation

Further Reading 


\section{PREFACE}

This book is intended to give horticultural students a background to the technological processes used in the commercial preservation of fruits and vegetables. It also covers in lesser detail a number of related topics including food-factory lay-out and essential services, and the composition and characteristics of suitable raw materials. A chapter has also been devoted to the underlying microbiological and biochemical aspects of preservation.

Students who are taking food studies in schools or colleges of domestic science and catering should also find the information useful.

As it was necessary to be selective about the amount of detail to be included, suggestions for further reading have been appended to most chapters. This will enable the reader to obtain more detailed information on specific topics of interest.

The suggestion that this book should be written came from Professor Leonard Broadbent, formerly of Bath University, and I am extremely grateful to him for his help and advice in the preparation of the manuscript. I am also grateful to Ms L. Bedford for supplying information on the raw-material aspects and to Ms R. Payne for typing the manuscript.

Chipping Campden, 1983

S. D. Holdsworth 